University for Business and Technology in Kosovo

UBT Knowledge Center

Nov 2nd, 9:00 AM - Nov 3rd, 5:00 PM

\title{
Communicating strategically - talking less, targeting better. Qualitative study on corporate communication's learning in leading global companies
}

Lukasz M. Bocheneki

University of Neuchatel, lukasz.bochenek@unine.ch

Sam Blili

University of Neuchatel

Follow this and additional works at: https://knowledgecenter.ubt-uni.net/conference

Part of the Business Commons

\section{Recommended Citation}

Bocheneki, Lukasz M. and Blili, Sam, "Communicating strategically - talking less, targeting better. Qualitative study on corporate communication's learning in leading global companies" (2012). UBT International Conference. 32.

https://knowledgecenter.ubt-uni.net/conference/2012/all-events/32

This Event is brought to you for free and open access by the Publication and Journals at UBT Knowledge Center. It has been accepted for inclusion in UBT International Conference by an authorized administrator of UBT Knowledge Center. For more information, please contact knowledge.center@ubt-uni.net. 


\title{
Communicating strategically - talking less, targeting better Qualitative study on corporate communication's learning in leading global companies
}

\author{
Lukasz M. Bochenek ${ }^{1}$, Sam Blili ${ }^{1}$ \\ ${ }^{1}$ University of Neuchatel (Enterprise Institute) \\ lukasz.bochenek@unine.ch
}

\begin{abstract}
Companies need to communicate strategically in order to maintain dialogue and relationships with their stakeholders. In the crowded media and social media space the messages disappear in the noise generated by multiple actors. Therefore, to be heard the enterprises need to consider their communication strategically. It is not about the amount of information, it is about right targeting and usage of the right tools and channels. Social media allowed the companies to communicate directly with their stakeholders and customers. Different channels can address different stakeholders. This study focuses on a qualitative assessment of the learning patterns and profiles among 60 world leading companies. It includes enterprises from different countries and industries but with international scope of operations. The study proposes a maturity model for corporate communications strategic management.
\end{abstract}

Keywords: Corporate communications, corporate reputation, social media, organizational learning

\section{Introduction}

New tools, like social media, offer companies new opportunities to communicate with stakeholders at both international and local levels. They can maintain direct dialogue with customers, influencers, multipliers and stakeholders. In that context Corporate Communications (CC) is becoming a core managerial function. It manages one of the most important intangible as sets of companies - corporate reputation (Minor and Morgan, 2011). Reputation building is a process which involves both communication and business strategy (Mohr et al., 2011). Therefore, "greenwashing" and other dis -honest corporate behaviors impact the reputation and can lead to communicational crises which impact bottom line of the company (Fearn-Banks, 2011). Communicational crises impact the brand and can have disastrous consequences for an enterprise. Toyota recall in 2010 is one of the most repeated examples. Therefore, the companies invest in their readiness and crisis mitigation. Training programmes and procedures are a "must" for the companies operating in high risk environments (Gonzalez-Herrero and Smith, 2010). That involves also building relationships with key stakeholders which can be used should a crisis arise. These relations are frequently initiated at the communicational level.

Sophistication of the tools requires sophistication of the $\mathrm{CC}$ as a business unit. This business function is driving corporate reputation and the driver needs to have a skill set needed to operate a complicated machine. That requires a learning of this unit and organization. The companies learn at three levels: operational, strategic and network one (Raymond and Blili, 1998). This learning allows creating sustainable communications procedures and strategies which improve managerial efficiency (Morsing and Schultz, 2006).

With the tremendous amount of information and communication in the web it is not about communicating more. It is about strategic targeting of the messages to reach relevant audiences and set agenda (Du et al., 2010). That may actually require communicating less. The size of clipping book is not a measure of success for the CC department. Actually CC moves from media relations management to become a part of overall enterprise's strategy.

In the following paper we will study 60 world's leading companies from various countries and industries in order to draw a picture of the learning patters and profiles among these companies. We will analyze the data in the light of the conceptual model and we will illustrate our findings and observations with selected examples. It will allow us to verify a conceptual model of the strategic corporate communications management and observe the organizational behaviors.

\section{Theory}

\subsection{Corporate Communications management}

Corporate Communication has been studied in different forms for over 40 years. The studies focused on the operational aspects of CC management. Several work analyzing managerial perspective focused on disclosure and senior executives' statements 
(Fiol, 1999). Other papers analyzed public relations and related techniques (Heath, 2010). That built an ecosystem in which corporate communications wasn't really studied from the multi-dimensional strategic perspective.

Acts of communication were studied much more in the media perspective. The interpretation of the message was a subject of numerous studies in the media and communication science (Maigret, 2005). The models included encoding -decoding of Stuart Hall which claimed that it is important to take into consideration the cognitive filters which analyzing message lecture (Hall, 1980). The intercultural aspect of communication is important from the organizational perspective (Hofstede, 2001). Important study of Hofstede provides insights to organizational communication (2001). While generalization of the conclusions to the overall intercultural communication is controversial, the company's communication system is described interestingly.

Corporate communication was treated as a tool/technique to build and sustain corporate image and/or reputation (Du et al., 2010, Wood, 2010). Several studies analyzed the impact of corporate image on the corporate performance in terms of competitive advantage (Orlitzky, 2008). The multi-level analysis focused more on the organizational techniques than the dialogue with stakeholders (Wood, 2010).

From the 1990' there is an agreement that the role of communications within companies is more important and that it is valuat ed positively by the senior executives (Crane, 2008). However, the CC has been analyzed from the perspective of corporate identity and reporting (Wood, 2010). Corporate reporting in the context of corporate image brings the question of the CSR reporting an $\mathrm{d}$ CSR information management (Du et al., 2010). Disclosure and communication with stakeholders can bring a competitive advantage (Melo and Garrido-Morgado, 2011).

\subsection{Corporate reputation}

Corporate image/reputation is one of the intangible assets of the corporation. It is to a certain extent measurable, th ough there are many objections to the current performance measurements conducted in the context of Corporate Social Performance (Wood 2010). The main objections arise by the fact that the data is mainly company centered (self-provided) and that third party criteria are also biased by the managerial perspective (i.e. Fortune's rank of the most admired companies is based on surveys among senior executives). This limitation of the corporate reputation measurement makes the issue closed in the managerial perspective (Gotsi and Wilson, 2001). Numerous studies focus more on the reputational damages expressed in stock exchange performance during the communicational crisis (Wood 2010). Therefore, there is a lack of stakeholders' perspective in these studies (2010).

There are several drivers of the corporate reputation. The industry in which company operates plays a crucial role (Maon et al., 2010). The companies from the "controversial" industries are less likely to benefit from the positive perception from stakeholders (Alniacik et al, 2001). The compliance and reporting of the compliance is another factor (Nielsen and Thomsen, 2007). Recently, the compliance has an extended meaning in which not only legal compliance is included (Wood, 2010). The companies actually voluntary and under stakeholders' pressure comply with international standards and regulations (Maon et al, 2010, Wood, 2010). Nevertheless, the pressure from stakeholders motivates companies to obey them (Alniacik et al., 2001). The CSR actions and reporting is another driver of corporate reputation. From the famous Cadbury report in 1994 companies do report on their environmental and social performance (Boyd, 1996). This reporting actually evolved from environmentally focused to socially focused (Wood, 2010).

Reputation is the asset which can be activated in order to create an advocacy around the brand, or its products (Wood 2010; Husted and Allen 2006). Advocacy is amplified by third party endorsement, especially important in the context of the CSR communications and community management ( $\mathrm{Du}$ et al 2010). The maximization of the CSR business returns is actually expressed in the terms of corporate communication benefits ( $\mathrm{Du}$ et al 2010). The slogan of the biggest PR firm worldwide Webershandwick "engaging always" shows well the accent in the communications industry.

\subsection{Corporate Social Responsibility - strategic communications}

Corporate communications aims to manage corporate reputation in order to gain the third party endorsement for the brand. In the current stakeholders' environment, corporate reputation is more important than it used to be. The growing role of multiple stakeholders and increased role of NGOs in the global agenda setting demand new levels of awareness for corporations (Ellis and Bastin 2011). The presence of actors from the Third sector in the media and their growing role in the agenda setting is not a threat for organizations (Minor and Morgan 2011). Indeed, it is an opportunity to enhance the benefits of CSR and CSP at the communicational level (Wood 2010). As stated by Wood, the communication on CSR is sometimes biased by the general public's willingness to "know the motives behind" corporate actions (Wood 2010). Therefore, partnerships create an opportunit y to gain a stable third party endorsement for CSR efforts (Wood, 2010). Rainforest certifications, partnerships with WWF, are just a few examples of corporations operationalizing these alliances at the communicational level (Husted and Allen 2006).

CSR is a part of business strategy which is driven by communicational and compliance needs of the corporation. The success of the CSR programme relies on stakeholders' mapping and communications (Burchell and Cook 2006). The most advanced companies address CSR with holistic models from compliance through sustainability to construction of the complex networks based on the business principles. The CSV triangle of Nestlé can be an example of this approach. The top of the pyramid is directly related to the corporate identity of Nestlé - its CSR/CSV programmes are based on the subjects mentioned on the top of the pyramid. The process starts with compliance and sustainability. This model can be adjusted in almost all industries, chan ging focus of the action at the CSV level. However, the most advanced organizations can attempt to create the value from networks. In the CSV model it is still corporation which follows the laws and social needs, but the real dialogue and value from the network is limited. The creation of industry clusters is one of the examples where corporations apply their CSR principles in 
creating added value for the communities. There constitutes a tangible benefit from corporate-public cooperation (Waddock and Mcintosh 2011). They bring together the networks of brand advocacies (Alniacik et al 2011).

The pressure comes from the creation of the hard laws which require companies to comply with stricter regulations. Summits such as Copenhagen, Durban, Cancun, put climate change and human impacts on the environment on the media agenda. The se meetings gathering world leaders on the subjects of ecology and sustainability define perception of the issue. Their media coverage is extensive and brings the is sues top-down to the country levels. Summits can be considered as the "media events" in the sense used by Dayan and Katz (Dayan and Katz 1992). In that sense their media coverage is guaranteed. However, the number of voices present in media is limited. The opinion is driven by the experts and political leaders. There is an opportu nity for international business to be part of this dialogue at the proactive level. The current programmes are reactive to the agenda set by other stakeholders. Even voluntary compliance and CSR programmes play a rather defensive role. The social media create a platform for multinationals to create proactive programmes which would build networks of stakeholders. The agenda of these networks can be driven by companies and build additional trust (Sharma et al 2011).

In the recent survey conducted by PR agency Edelman the transparency of business practice was judged almost as important as the quality of products and services (Edelman 2011). It is another argument highlighting a potential of social media. They are an uncontrolled source of information and can be used to build transparency which starts to be executed in politics (Terblanche 2011: Waters and Williams 2011). Business plays also a more crucial role in the globalized context. The international structu res make introduction of the global standards dependent on companies (Scherer and Palazzo 2011). The advanced advocacy programmes play in that context a crucial role in international management (ibid.).

Trust in business increased in recent years, especially on the auto-referral level (Edelman 2011). Trust in messages passed by CEOs has increased after the temporary decrease due to the financial crisis. The role of CEO's messaging cannot be underestimated as the case of BP showed (Fearn-Banks 2011). Moreover, the social media become incorporated in the crisis communications strategies (Veil et al 2011).

The most trusted industry is technology which is probably the less concerned by the world issues related to sustainability (Edelman 2011). The risk related to escalation of e-waste issue seems to be mitigated. Relatively high rankings of biotech and pharmaceutical industries at the level of trust may be explained by media focus in last 3 years on the issues related to fina ncial sector and lack of global communicational crisis related to pharma products.

\subsection{Organizational learning of the Corporate Communications}

Companies, corporations and organizations learn and nowadays this learning is faster and more intense than ever before. It happens when business units, production units, which can be bigger or smaller, more or less sop histicated, acquire knowledge or savoir-faire which has a recognized potential for the organization (Morgan 1986, Raymond and Blili 2001). To be more precise, the learning is a result of four processes (Huber 1991): acquisition of knowledge, sharing of knowledge, interpretation and analysis of information and organizational memory (for the further use of knowledge). From that we deduct that learning requires new information systems for the knowledge or competences (collection, storage, distribution, application, canalization and protection of the information and competences). That is valid for creation of the added value at the same level as for mastering of organizational concerns such as: corporate image, intangible assets, or even corporate communications (CC), or a more sophisticated form of this concern - social marketing.

The question of Corporate Communications (CC) is confronted today with double issues. First, the legitimacy of the public and private institutions was never so low. Enterprises never faced that level of public reservation. Actions orchestrated by NGOs, or even customers themselves, may become boycotts and protests (Shumate and O'Connor 2010). The tension and quest for the legitimacy of business result in the reincarnation of corporate communications. From a nice-to-have-business function, which communicated organizational news, CC became a core managerial concern and in consequence core managerial function (Du et al 2010). Marketing is either social or it doesn't exist. Moreover, the explosion of communication technologies posed a serious threat to the corporations which were exposed to public criticism and judgment of their actions. All local crises got the glo bal potential to influence business and corporate activities (Gonzalez-Herrero 2008). The externalization can bring benefit of lighter corporate structure and partner flexibility i.e. innovative SME (Butera 1991). New forms of work and cooperation see the day such as network enterprise, shared services, or cloud as an organizational as set and structure. These new structures, new business models, imply new forms of interaction between corporations and SMEs (Blili and Raymond 1993). In order to become competitive, the GE as well as SMEs need to integrate the ICTs, management of intang ible assets (AI) into their operations, tactics and even into their strategies in re-engineering their internal and external processes (Raymond et al 1998; Raymond and Blili 2001). It is obvious that this integration will vary from enterprise to enterprise. However, grouping of enterprises (cluster), or network, should lead to "rich communication" and the synergy between business partners should take place. These networks and partnerships may include also partners from the Third sector (Shumate and O'Connor 2010). Organizational learning is one of the core elements of the organizational transformation and drives clear business benefits (Blackman and Henderson 2005). The study analyzes the OL of the social media and also the sophistication of the CC as a business unit. The dual focus allows analyzing the process of the building of organizational learning (Garvin 1993).

\subsection{Towards the maturity model}

This study aims to propose a maturity model of corporate communications. The business function of corporate commun ications plays an increasing role in the overall enterprise's strategy (White 1994). With the increased role of corporate reputation, the 
is sues management, stakeholders' management, CSP communications and crisis communications became the core managerial functions. They manage the important intangible assets of the company. On top of the more sophisticated tools available for bo th corporate communicators and their counterparties from consumer groups and NGOs, the role of societal issues gained momentum among the most important stakeholders. The model below is drawn from the literature overview and inspired by Raymond and Blili proposals (2001) and their application to in the context of IP management in SME companies (Gibb and Blili forthcoming).

\subsection{Introduction of the archetypes}

The companies learn individually and collectively (Raymond and Blili, 1993). This learning process is accelerated by the mobility of individuals working in different companies and bringing their experiences. Exchange which is created builds on experience of both (an individual and an organization). Proposed archetypes are inspired by the previous researches on IA management in the SME enterprises (Gibb and Blili, 2012 a,b,c).

Table 1 Learning profiles of CC management

\begin{tabular}{|c|c|c|c|c|}
\hline Sleeping & Passive & Reactive & Active & Thought leader \\
\hline $\begin{array}{l}\text { The companies representing this } \\
\text { archety pe do not consider CC as } \\
\text { important in their corporate } \\
\text { strategy. Their activities in the } \\
\text { domain of communication are } \\
\text { rather non-existing. They do not } \\
\text { embrace social media nor other } \\
\text { communicational tools. These } \\
\text { companies are afraid of } \\
\text { communication which exceeds } \\
\text { legal requirements. The focus } \\
\text { might be on marketing, or they } \\
\text { operate in niche markets and } \\
\text { don't perceive the value of } \\
\text { communications for business } \\
\text { operations. These organizations } \\
\text { may have communication } \\
\text { channels, however these channel } \\
\text { are not used more than to } \\
\text { communicate internal } \\
\text { information. }\end{array}$ & $\begin{array}{l}\text { The companies which are passive } \\
\text { do not create their corporate } \\
\text { communications strategies. They } \\
\text { use the communicational tools } \\
\text { more to monitor the situation and } \\
\text { the brand than to actually drive } \\
\text { communications and public } \\
\text { relations programmes. These } \\
\text { companies use social media to } \\
\text { post corporate messages, but do } \\
\text { not differentiate between the } \\
\text { channels. The usage of the } \\
\text { technology is limited to the } \\
\text { ty pical corporate messaging. The } \\
\text { learning occur at individual level } \\
\text { and potentially at the team level. } \\
\text { The communications team is not } \\
\text { valued inside of the organization } \\
\text { and is positioned relatively low in } \\
\text { the corporate structure. The } \\
\text { budget for CC is limited. Senior } \\
\text { executives don't perceive the } \\
\text { need to step and act as } \\
\text { spokespeople of the organization. }\end{array}$ & $\begin{array}{l}\text { Companies representing this } \\
\text { archety pe use social media and } \\
\text { CC in their strategy. They do not } \\
\text { create a leadership in the domain } \\
\text { of communications, but rather } \\
\text { follow the overall trends from } \\
\text { their industries. Their CSP is part } \\
\text { of the strategy and follows the } \\
\text { trends from the industry in which } \\
\text { they operate. Learning includes } \\
\text { extensive monitoring procedures } \\
\text { and occurs at the departmental } \\
\text { level. Department and head of } \\
\text { communications benefit from } \\
\text { high hierarchical level within the } \\
\text { organization. Communication is } \\
\text { one of the concerns of senior } \\
\text { executive team and benefits from } \\
\text { the important budget. The } \\
\text { perception is still comparative to } \\
\text { the peers and competitors. }\end{array}$ & $\begin{array}{l}\text { The companies have clear role of } \\
\text { CC which is expressed by } \\
\text { importance of the budgets agreed } \\
\text { to CC and social media. They } \\
\text { create new areas for their CSR } \\
\text { programmes, which position } \\
\text { them at the leadership positions } \\
\text { within respective industries. They } \\
\text { can set industrial trends in the } \\
\text { communications and CSR } \\
\text { approaches. The CC is integrated } \\
\text { in the strategy of the enterprise. } \\
\text { The head of com munications } \\
\text { benefits from the position at the } \\
\text { board level within the } \\
\text { organization. The budgets for } \\
\text { communications are important } \\
\text { and communications is a driver of } \\
\text { promotional efforts within the } \\
\text { organization. There are signs of } \\
\text { transformative learning with the } \\
\text { organization, however the main } \\
\text { focus remains internal. }\end{array}$ & $\begin{array}{l}\text { The companies representing this } \\
\text { archety pe are gurus in the } \\
\text { domain. They embrace fully CC } \\
\text { and agree to an important part of } \\
\text { the budget for these activities. } \\
\text { The executives managing CC in } \\
\text { these organizations sit at the } \\
\text { board level. The leadership is } \\
\text { based on the principles of } \\
\text { corporate identity which exceeds } \\
\text { the requirements of CSP. The } \\
\text { activities of these companies set } \\
\text { the agenda of stakeholders in the } \\
\text { issue. The CSR programmes are } \\
\text { executed in the network of } \\
\text { partners through PPPs and } \\
\text { clusters. The CSR and CC are not } \\
\text { cost centers but elements of } \\
\text { corporate value creation. } \\
\text { Learning occurs in the network } \\
\text { which creates also common } \\
\text { communicational platforms. } \\
\text { Communications is one of the top } \\
\text { priorities and drives the changes } \\
\text { in the business practices. }\end{array}$ \\
\hline
\end{tabular}

Each of the archetypes involves operations at different levels of organizational learning. After the theory review and initial analysis, the researchers created a model of the organizational leaning patterns and practices. Sophistication of the learning process occurs in two directions. The company moves into more sophisticated profiles. Moreover, the companies learn in more sophisticated way by using more sophisticated learning patterns.

Table 2 Learning patterns of $\mathrm{CC}$ management

\begin{tabular}{|c|c|c|c|c|c|c|}
\hline & & Sleeping & Passive & Reactive & Proactive & Thought leader \\
\hline \multirow{4}{*}{ 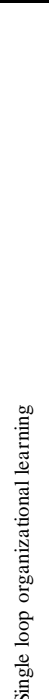 } & 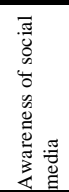 & $\begin{array}{l}\text { No presence on the social } \\
\text { media channels }\end{array}$ & $\begin{array}{l}\text { Social media used as the CC } \\
\text { push channel }\end{array}$ & $\begin{array}{l}\text { Social media adopted to the } \\
\text { events and activities of the } \\
\text { company }\end{array}$ & $\begin{array}{l}\text { Social media is integrated to } \\
\text { the activities of the company } \\
\text { and there is asocial media } \\
\text { policy }\end{array}$ & $\begin{array}{l}\text { All the staff of the company } \\
\text { is trained in the social media } \\
\text { usages }\end{array}$ \\
\hline & 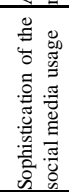 & $\begin{array}{l}\text { Not using social media } \\
\text { platforms }\end{array}$ & $\begin{array}{l}\text { Using the platforms to show } \\
\text { corporate messages. Static } \\
\text { profile pages. Lack of } \\
\text { innovation. }\end{array}$ & $\begin{array}{l}\text { Interacting with the } \\
\text { fans/followers (i.e. questions } \\
\text { to the fans) }\end{array}$ & $\begin{array}{l}\text { Interacting, responding and } \\
\text { commenting on the fans' } \\
\text { activity. }\end{array}$ & $\begin{array}{l}\text { Real time responsiveness } \\
\text { across time zones of } \\
\text { corporate operations. }\end{array}$ \\
\hline & $\begin{array}{l}\frac{ \pm}{5} \\
0 \\
0\end{array}$ & no presence & $\begin{array}{l}\text { presence of the corporate } \\
\text { communications as a separate } \\
\text { job department }\end{array}$ & $\begin{array}{l}\text { Dedicated CC contacts on } \\
\text { the website (i.e. for media, } \\
\text { investors etc.) }\end{array}$ & CC team presented & $\begin{array}{l}\text { Personalized social media } \\
\text { messages signed by the } \\
\text { members of CC team }\end{array}$ \\
\hline & 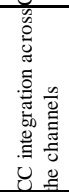 & not present & $\begin{array}{l}\text { standard lay out of the social } \\
\text { media platforms }\end{array}$ & $\begin{array}{l}\text { branded presence with } \\
\text { corporate logo and } \\
\text { information }\end{array}$ & $\begin{array}{l}\text { applications, quizzes, games, } \\
\text { videos and interactive content } \\
\text { on the social media }\end{array}$ & $\begin{array}{l}\text { providing whole fans' joumey } \\
\text { from welcome page to the } \\
\text { updates and off-platform } \\
\text { interaction }\end{array}$ \\
\hline
\end{tabular}




\begin{tabular}{|c|c|c|c|c|c|c|}
\hline & 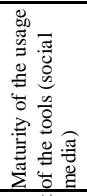 & no presence & $\begin{array}{l}\text { newly established practice } \\
\text { and accounts }\end{array}$ & $\begin{array}{l}\text { regular and uninterrupted } \\
\text { presence on social media } \\
\text { platforms }\end{array}$ & $\begin{array}{l}\text { presence on the platforms } \\
\text { from their begging }\end{array}$ & $\begin{array}{l}\text { social media as a part of } \\
\text { corporate communications } \\
\text { campaigns and offline } \\
\text { activities }\end{array}$ \\
\hline & 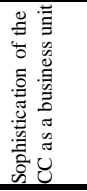 & $\begin{array}{l}\text { Non existence of CC } \\
\text { department }\end{array}$ & $\begin{array}{l}\text { CC department existing - } \\
\text { media relations activities }\end{array}$ & $\begin{array}{l}\mathrm{CC} \text { regular activity beyond } \\
\text { routine press releases }\end{array}$ & $\begin{array}{l}\text { CC reactive activities, defined } \\
\text { spokesperson, crisis } \\
\text { communications readiness }\end{array}$ & $\begin{array}{l}\text { CC proactively present - } \\
\text { website and communication } \\
\text { adapted to respective groups } \\
\text { of stakeholders }\end{array}$ \\
\hline \multirow{2}{*}{ 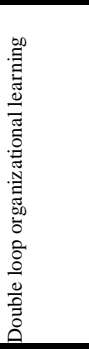 } & 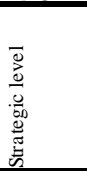 & & $\begin{array}{l}\text { Specific corporate } \\
\text { communications department }\end{array}$ & $\begin{array}{l}\text { Presence of the digital and } \\
\text { regular corporate press of fice }\end{array}$ & $\begin{array}{l}\text { Board level presence of the } \\
\text { head of corporate } \\
\text { communications }\end{array}$ & $\begin{array}{l}\text { Social media and } \\
\text { communications as a central } \\
\text { driver of marketing effort }\end{array}$ \\
\hline & 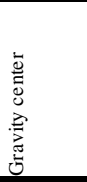 & & $\begin{array}{l}\text { Presence of the corporate } \\
\text { mission, vision values in the } \\
\text { CC }\end{array}$ & $\begin{array}{l}\text { Social media integrated in } \\
\text { the all CC activities }\end{array}$ & $\begin{array}{l}\text { Corporate communications } \\
\text { driving interdepartmental } \\
\text { strategy }\end{array}$ & $\begin{array}{l}\text { Corporate communications } \\
\text { driving the business strategy } \\
\text { of the enterprise }\end{array}$ \\
\hline 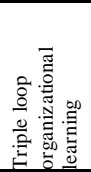 & 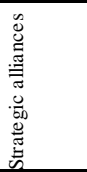 & $\begin{array}{l}\text { company centered on the } \\
\text { operations only }\end{array}$ & $\begin{array}{l}\text { presence of } \\
\text { CSR/sustainability section on } \\
\text { the website }\end{array}$ & $\begin{array}{l}\text { presence of vision, mission } \\
\text { and values on the corporate } \\
\text { channels of communication }\end{array}$ & $\begin{array}{l}\text { existence of foundation, } \\
\text { partnership programmes with } \\
\text { multiple stakeholders }\end{array}$ & $\begin{array}{l}\text { Communications and social } \\
\text { media activities based on the } \\
\text { interactions with the } \\
\text { stakeholders, daily contacts } \\
\text { with the stakeholders, } \\
\text { externalization of the } \\
\text { communications }\end{array}$ \\
\hline
\end{tabular}

\section{Methods}

\subsection{The research study}

The design of the methodology of the research is inspired by methodological proposals of Hamilton and her study on entrepreneurial learning (Hamilton 2011). It draws also from Bezançon and Blili's proposals of case studies analyses of fair trade behaviors of the Swiss companies (Bezançon and Blili 2008).

The study included 60 world leading companies. The analysis and observations presented in this paper is but one interpretation of the empirical material with no intention to generalize the findings (Hamilton 2011). Rather the empirical data offers some tentative support for the theoretical propositions of the strategies in social media corporate management (Hamilton 2011). However, the trends based on 60 world's leading companies allow drawing proposals related to the best practice in the CC management.

\subsection{Research design}

\section{First stage - exploratory study}

The research presented in this paper included several steps. First, the researchers conducted 18 semi-structured exploratory interviews with the senior communications executives from private sector and third sector organizations. It allowed refining the definitions used in the conceptual model and its application in the context of qualitative study (Bochenek and Blili, 2012). After that, the model was applied in the context of 5 companies representing almost "ideal" learning profiles. The aim of this step was to construct an observation model which would be applicable to maximum number of companies.

\section{Second stage - case studies}

Most of the communications activities of the companies are visible externally and the model helped to assess the operations in the context of organizational strategies. The observation model is based on the conceptual dynamic model of CC strategic management. It includes also drivers of CC management. Each of the descriptions for each criterion aims to include maximum variety of the potential operations of the companies. For each company we looked at the corporate communications materials. We analyzed also the website (sections: about, vision, history, management, CSR/sustainability, media/press office, press releases both on the corporate and local levels), corporate Twitter account, other Twitter accounts, Facebook corporate and product accounts, Flikr, You Tube and other social media (Pinterest, Google +).

\subsection{The sample}

The study is based on 60 companies. The sampling is theoretical rather than random to clearly illustrate corporate behavioral patterns (Yin 2003).

We included the companies from different regions and industries. A purposive sample is determined by the experience of the processes being studied that any particular individual or group may be able to draw upon (Hamilton 2011). The companies are therefore selected basing on their ability to showcase best the practices. The companies are in that approach playing the ro le of "experiential experts" (Morse 1995). In that sense we observe each of the patterns and each of the profiles presented in our conceptual. 
The selection process, although based on theoretical sampling, also included elements of calls "maximum variety sampling" in selecting a heterogeneous sample (Morse 1995; Hamilton 2011). We looked at the global companies from various sectors with international scope of operations. We included both $b 2 b$ and $b 2 c$ companies. The decision to focus on large companies was driven by the fact that they tend to have larger and more visible communications operations.

\subsection{Analytical process}

We analyzed the contents of the publically available materials related to the companies' communications operations according to the research model. All the companies have been analyzed which allowed us to draw the models of the most "typical" learning patterns and profiles. We analyzed each criterion to see how the sophistication process occurs both within the companies and in general. We then compared the learning behaviors of the companies with their industries and geographical location to assess the impact of these variables on the OL.

\section{Analysis}

\subsection{Operational level}

Companies embrace CC as a tool for marketing. It is especially visible on social media. Over $90 \%$ of the analyzed companies have their presence on social media channels. The usage of these channels varies ranging from "additional websites" which secure the presence of the company on new channels to complex strategies which allow provide users with a full customer journey including off-line interaction and dialogue. Social media usage involves CC, marketing, but in many cases also CRM, HR and other job functions. In the most advanced cases, the companies are using social media in R\&D activities i.e. crowdsourcing. Also, the communication which is present on each channel is directed and tailored to the respective groups of stakeholders. Several companies create the Facebook and Twitter accounts which are managed by the regions, or business units. In that case social media have a role of an additional communication channel rather than marketing.

Corporate Communications for a long time was focused on the media relations. Sending press releases, pitching media stories were the most visible activities of the department. Creating and managing media lists was one of core activities of PR agencies. Today, with increased role of bloggers and industry experts the question of media relations is more complex. Certainly media management systems like Factiva media lists or Vocus make the search and targeted pitching much easier. However, the companies need also to be easily reachable for these multiplied media stakeholders. Therefore, the role of digital press office is crucial. In the case of analyzed companies it has several roles:

- $\quad$ Providing press releases

- Providing media kits, bios and approved multi-media materials

- Providing media contact for journalist's (in the most advanced forms divided into subject areas and geographies)

- $\quad$ Providing RSS and social media feeds (i.e. Twitter account for media relations)

The number of provided contacts and situation of the digital press office on the website shows the importance which is attach ed to the media relations activities of the company.

Corporate websites are also an important indication of CC operational sophistication. The websites of the analyzed companies range from static " 90 ' style websites to the multi-media hubs which are directed to the various groups of stakeholders. The companies, for which corporate brand is important for sales and competitiveness, have developed advanced websites which are culturally and linguistically adapted to the respective stakeholders globally. The companies which have product brands tend to have less developed corporate websites. In the sophistication process the website is a corporate channel which can be easily adapted by user to become a "tailored" communication channel.

Overall the advanced tools give to companies an opportunity to build their communicational presence across the channels and platforms. The communication includes here business units: CC, marketing, HR, CRM, R\&D as well as geographic locations. Media and social media hubs on the corporate websites are the best example of the inter-connectivity between the channels.

\subsection{Strategic level}

Strategic level and gravity center of the CC can be analyzed from the operations of the companies. Several of the analyzed companies have placed the head of $\mathrm{CC}$ at the board level of their organizations. In the case of one company 3 senior executive $\mathrm{s}$ in the management board have a role supervising the areas of communication. However, the majority of the companies still doesn't consider CC as a board level function. It is frequently situated under sales and marketing.

Nevertheless, the gravity center of CC is important in the case of majority of companies. CC drives the interdepartmental communications and business programmes adapted to various audiences. The strategic choices are reflected in the place which $\mathrm{CC}$ occupies in the overall business strategy. Companies build their organizational essence (mission, vision, values) to create an organizational culture. This culture is frequently strengthened by the "founding myth" which is presented in the company's history. The alignment of the CC operations with the corporate essence is another sign of corporate CC strategy. 


\subsection{Network level}

Corporate Social Responsibility provides companies with the framework which allows them to address their stakeholders directly. CSR operations in the analyzed companies range from compliance with the standards and reporting to the multi-partner clusters and PPPs. A communication around sustainability programme of the company builds internal identity. In the analysis several strategies and processes have been identified:

- Top-down CSR programmes which involve strong ideological factor and build organizational identity (i.e. Nestle)

- Wide CSR programmes driven by brand communication. CSR communication is implemented to the product level (i.e. Unilever)

- Philanthropic programmes involving education, art etc. (mainly banks)

- Environmental programmes focused on reporting and ad-hoc activities in the developing countries (oil companies)

The level of triple loop organizational learning in CSR programmes varies. In the case of CSR enviro nmental reporting and adhoc activities it is rather limited. These programmes are company focused and company driven and the partners provide legitimacy for the action. The programmes involving corporate foundation provide a platform for organizational le arning from the partners. However, this learning is again limited by the fact that these programmes are company driven. It is at the level of multi-organizational programmes based on PPPs and clusters.

\subsection{Drivers of CC organizational learning}

Research allowed us to identify several drivers of CC management.

Industry: the industry and competitors' activities are the drivers for CC strategic management. Although in each sectors there are several easily identifiable "communication champions", the operations are similar. For example oil companies focus on their environmental performance, the banks on CRM services on-line, FMCG companies on brand related activities etc.

Geographical location - CC analysis are biased by the Western paradigm. The communicational culture in the in China is different than in U.S. and Europe. Also, the legal framework for communication varies according to location. Therefore, the origins of company influence strongly corporate culture and then CC management strategies and practices.

Scope of activities - the companies which are leaders in multiple sectors tend to be more sophisticated in their CC learning processes. These companies interact with multiple stakeholders regularly. Also, the polyvalent structure seems to be more ope n to innovation in strategic management including CC.

Importance of the brand for competitiveness - the companies which operate in b2c sector are much more present on social media channels. They are also adapting the channels linguistically and culturally to embrace the most important number of potential clients.

\section{Discussion}

Corporate communications valuation by the world's biggest companies varies. Different strategies are driven by the cultural contexts as well as industries in which companies operate. Although, there are international standards and practices in CC management it seems that the execution is culturally driven. Companies based in United States, South America and Europe seem to be more open to new communication tools such as social media. The roll out of the communications strategies needs to be analyzed at two levels: global corporate one and the local ones. Centrally situated CC department manages overall corporate reputation while the operations are executed at the regional and country levels.

\section{Conclusions}

Organizational learning of the CC strategic management is driven mainly by the factors which are external to the organization . CC management is also highly influenced by the cultural background of the company especially at the level of social media management. The companies tend to differentiate the channels of communication. There are corporate global accounts and local accounts in the respective languages. Companies which have strong product brands tend to put more effort on brand communications and brand driven channels (especially in FMCG sector). Therefore, the social media visibility and interaction needs to be contextualized for each company. The simple measure of the corporate account seems to limit the scope of analyzed operations.

Advanced learning of $\mathrm{CC}$ involves organizational roll-out and inter-connectivity between the channels. Therefore, the companies use social media and other communication tools to drive the activities from different job functions (i.e. recruitment, R\&D e tc.). Strategic level and internal gravity of corporate communications can be perceived externally. The channels are adapted to the respective groups of stakeholders. There is language and cultural adaptation of the corporate materials for different groups of stakeholders and customers. The companies inter-link the channels which facilitates the dialogue with the respective stakeholders. Moreover, there is an important role of senior management who embraces communications. In several global companies CEOs play a role of spokespeople of their organizations. It happens not only in the context of the crisis, but also in the regular times. Role of CEOs in CC is non-negligible. They do represent the companies in the international forums (i.e. WEF) and in front of the authorities. The visibility of the CEO seems to drive strategic efforts of the companies in the CC strategic management. 


\subsection{Limitation and further research}

This qualitative research based on the content analysis gives an insight to the CC operations and management in the world's biggest companies. In order to gather data from maximum number of companies, the researchers decided to base analysis on the content analysis of the websites and other corporate communications channels including social media. The analysis included over 400 various pages, profiles and accounts. This approach allowed to draw some conclusions related to CC strategic management. However, this research can only propose some conclusions which are driven by the conceptual model. The conclusions cannot be considered as a final "state of art" of CC management.

It would be interesting to study internal organization of the CC departments and actual learning of the CC from the perspective of both experts and companies. That would allow drawing more advanced conclusions based on a quantitative sample. In the second step, it would be interesting to study the perception of the CC operations from the point of view of target audiences: general public and stakeholders. That would allow assessing the perception of all the actors participating in the communication system. 


\section{References}

Alniacik U,.Alniacik E., Genc N. (2011). How Corporate Social Responsibility Information Influences Stakeholders' Intentions, Corporate Social Responsibility and Environmental Management 18, 234-245.

Blackman, D.A., Henderson, S. (2005). Why Learning Organisations Do Not Transform, The Learning Organization Journal, 12 (1); 42-45.

Blili S., Raymond, L. (1993). Information Technology: Threats and Opportunities for SMEs. International Journal of Information Management 13 (6), 439-448

Boyd C., Ethics and Corporate Governance: The Issues Raised by the Cadbury Report in the United Kingdom, Journal of Business Ethics 15 (2), 167-182.

Burchell J., Cook J. (2006). Assessing the impact of stakeholder dialogue: changing relationships between NGOs and companies. Journal of Public Affairs 6, 210-227.

Burrell M. (2011). A decade of change and continuity in public affairs. Journal of Public Affairs 12 (1), 74-76.

Butera F., (1991). La Métamorphose de l'Organisation, du Château au Réseau, Les Editions d'Organisation.

Crane A., Matten D. (2005). Corporate Citizenship: Missing the Point or Missing the Boat? A Reply to van Oosterhout, The Academy of Management Review 30 (4) (Oct., 2005). 681-684.

Crane A. (ed.) (2009). The Oxford handbook of Corporate Social Responsibility, Oxford University Press.

Dahlsrud A. (2006). How Corporate Social Responsibility is Defined: an Analysis of 37 Definitions. Corporate Social Responsibility and Environmental Management 15, 1-13.

Dayan D., Katz E., (1992). Media Events: The Live Broadcasting of History, Harvard University Press.

Du S., Bhattacharya C.B. Sen S. (2010). Maximizing Business Returns to Corporate Social Responsibility (CSR): The Role of CSR Communication, International Journal of Management Reviews 12 (1), 8-19.

Dylan Minor and John Morgan (2011). CSR as Reputation Insurance: Primum Non Nocere, California Management Review, 53, 3 (Spring 2011). 40-59.

Edelman, Trust barometer, http://www.edelman.com/trust/2011/, accessed 30.06.2012

Edelman, Trust barometer, http://www.edelman.com/trust/2012/, accessed 30.06.2012.

Ellis L., Bastin C., (2011). Corporate Social Responsibility in Times of Recession: Changing Discourses and Implications for Policy and Practice. Corporate Social Responsibility and Environmental Management 18, 294-305.

European Communication Monitor 2012. Challenges and Competencies for Strategic Communication. Results of an Empirical Survey in 42 Countries. Brussels: EACD/EUPRERA.

Fearn-Banks K. (2011). Crisis Communications: A case studies approach, Routledge.

Fiol M. (1999). Corporate communications: comparing top executives private and public statements. The Academy of Management Journal 38 (2), 522-536.

Fisher T. (2009). ROI in Social Media: A Look at the Arguments. Database Marketing and Customer Strategy 16 (3), 189-195.

Garvin D. (1993). Building a learning organization, Harvard Business Review 71 (4) (July-Aug. 1993).

Gibb Y. K., Blili S. (2012, a). A maturity model for intellectual asset governance at SME level, 2nd Annual International Conference on Innovation and Entrepreneurship IE 2012, 23 - 24 July 2012 (forthcoming).

Gibb Y. K. \& Blili S. (2012, b). Characterizing management of intellectual assets in SME: identifying learning patters, IABPAD Conference, August 2-5, 2012 (forthcoming).

Gibb Y. K. \& Blili S. (2012, c). Business Strategy and Governance of Intellectual Assets in Small \& Medium Enterprises, 2nd International Conference on Leadership, Technology and Innovation Management, 11 -13 October 2012 (forthcoming)

Gibb Y. K., Blili S (2012, d). A critical review and dynamic model of intellectual assets and rights corporate governance. Working Paper, IENE-University of Neuchâtel, (forthcoming).

Gibb Y. K., Blili S (2012, e). Towards a Definition of Intellectual Capital and Intellectual Assets. Working Paper, IENEUniversity of Neuchâtel, (forthcoming).

Gotsi M., Wilson A., (2001). Corporate reputation: seeking a definition, Corporate Communications: An International Journal 6 (1), $24-30$.

Gonzalez-Herrero A., Smith S. (2008). Crisis Communications Management on the Web: How Internet-Based Technologies are Changing the Way Public Relations Handle Business Crises. Journal of Contingencies and Crisis Management 1 (3), 143-153.

Hall S. (ed.). (1980). Culture, Media, Language: Working Papers in Cultural Studies, 1972-79 (Cultural Studies Birmingham), Routhledge.

Hamilton E., (2011). Entrepreneurial learning in family business: A situated learning perspective. Journal of Small Business and Enterprise Development 18 (1), 8 - 26.

Heath R., (2010). The SAGE Handbook of Public Relations, Sage.

Hofstede, G. (2001). Culture's consequences: Comparing values, behaviors, institutions, and organizations across nations (2nd ed.). Thousand Oaks, California: Sage Publications, Inc. 
Huber G., (1991). Organizational Learning: The Contributing Processes and the Literatures. Organization Science, 2, 1, Special Issue: Organizational Learning: Papers in Honor of (and by) James G. March. 88-115.

Husted B. W., Allen D. B. (2006). Corporate Social Responsibility in the Multinational Enterprise: Strategic and Institutional Approaches, Journal of International Business Studies, 37 (6), Three Lenses on the Multinational Enterprise: Politics, Corru ption and Corporate Social Responsibility (Nov., 2006). 838-849.

Maigret E., (2007). Sociologie de la communication et des médias, Paris, Armand Colin, (2e édition).

Maon F., Lindgreen A., Swaen V. (2010). Organizational Stages and Cultural Phases: A Critical Review and a Consolidative Model of Corporate Social Responsibility Development. International. Journal of Management Review 12 (1), 20-38.

Melo T., Garrido-Morgado A. (2011). Corporate Reputation: A Combination of Social Responsibility and Industry. Corporate Social Responsibility and Environmental Management 19 (1), 19-31.

Minor D. and Morgan J. (2011). CSR as Reputation Insurance: Primum Non Nocere, California Management Review 53 (3) (Spring 2011). 40-59.

Mohr L. A., Webb D. J., Harris K. (2001). Do Consumers Expect Companies to be Socially Responsible? The Impact of Corporate Social Responsibility on Buying Behavior. The Journal of Consumer Affairs 35 (1), 45-72.

Morgan G., (1986). Images of organization, SAGE.

Morse, J.M. (1995) Designing funded qualitative research, [in:] Denzin, N.K. and Lincoln, Y.S. (Eds). Handbook of Qualitative Research. Sage. Thousand Oaks, CA.

Morsing and Schultz (2006). Corporate Social Responsibility Communication: Stakeholder Information Response and Involvement Strategies. Journal of Communication 15 (4), 323-338.

Nielsen, A. E. \& Thomsen, C. (2007). 'What they say and how they say it'. Corporate Communications: An International Journal, 12 (1), 25-40.

Orlitzky, M. (2008). Corporate social performance and financial performance: A research synthesis. In A. Crane, A. McWilliams, D. Matten, J. Moon, \& D. S. Siegel (Eds.), The Oxford Handbook of CSR. Oxford, UK: Oxford University Press. Parkhe A., (1991). Interfirm Diversity, Organizational Learning and Longevity in global Strategic Alliances. Journal of International Business Studies 22, 579-600.

Parum E., (2006). Corporate Governance and Corporate Identity. Corporate Governance: An International Review 14 (6), 558567.

Raymond L., Blili S. (1993). Information Technology: Threats and Opportunities for SMEs, International Journal of Information Management 13 (6), 439-448.

Raymond L., Blili S., Rivard S. (1998). Impact of Task Uncertainty, End-User Involvement, and Competence on the Success of End-User Computing. Information \& Management 33 (3), 137-153.

Raymond L., Blili S. (2001). Organizational Learning as a Foundation of Electronic Commerce in the Network Organization. International Journal of Electronic Commerce 5 (2), 29-45.

Regester M., Larkin J., (2005). Risk Issues and Crisis Management in Public Relations: A Casebook of Best Practice, Kogan Page Publishers.

Scherer A.G., Palazzo G. (2011). The New Political Role of Business in a Globalized World: A Review of a New Perspective on CSR and its Implications for the Firm, Governance, and Democracy. Journal of Management Studies 48 (4), 899-931.

Sharma N., Butler B. S., Irwin J., Spallek H. (2011). Emphasizing Social Features in Information Portals: Effects on New Member Engagement, Journal of the American Society for Information Science and Technology 62 (11), 2106-2120.

Shumate M., O'Connor A. (2010). The Symbiotic Sustainability Model: Conceptualizing NGO-Corporate Alliance Communication, Journal of Communication 60, 577-609.

Stead E., Smallman C. (1999). Understanding business failure: Learning and un-learning lessons from industrial crises. Journal of Contingences and Crisis Management 7 (1), 1-18.

Sweetser K. D. (2010). A Loosing Strategy: The Impact of Nondisclosure in Social Media on Relationships. Journal of Public Relations Research 22 (3), 288-310.

Terblanche N. S. (2011). "You cannot run or hide from social media-ask a politician". Journal of Public Affairs 11 (3), $156-$ 167.

Veil S. R., Buehner T., Pakenchar M. J. (2011). A Work-In-Process Literature Review: Incorporating Social Media in Risk and Cris is Communication. Journal of Contingencies and Crisis Management, 19 (2), 110-122.

Waddock S., Mcintosh M., (2011). Business Unusual: Corporate Responsibility in a 2.0 World, Business and Society Review 116 (3), 303-330.

Waters R.D., Williams J. M. (2011). Squawking, tweeting, cooing, and hooting: analyzing the communication patterns of government agencies on Twitter, Journal of Public Affairs (2011).

Weaver G. R., Trvino L. K., Cochran P. L. (1999). Integrated and decoupled Corporate Social Performance: Management commitments, external pressures and corporate ethics practices. The Academy of Management Journal, 42 (5), 539-552.

White J. (1994). Strategic communications management: making public relations work, Wokingham

Wood D.J. (2010). Measuring Corporate Social Performance: A Review. International Journal of Management Reviews, 12 (1), 50-84.

Yin, R. K. (2003). Case study research: Design and methods (3rd ed.). Thousand Oaks, 
Zellweger T. M., Nason R. S., Nordqvist M., Brush, C. G. (2011). Why Do Family Firms Strive for Nonfinancial Goals? An Organizational Identity Perspective, Entrepreneurship Theory and Practice, 1- 20.

Ziek P. (2009). Making Sense of CSR Communication. Corporate Social Responsibility and Environmental Management 16, $137-145$.

Zyglidopoulos S.C. (2003). The Impact of Downsizing on the Corporate Reputation for Social Performance, Journal of Public Affairs 4 (1), 11-25. 